\title{
Digestive development in neonatal dairy calves with either whole or ground oats in the calf starter ${ }^{1}$
}

\author{
F. X. Suarez-Mena, ${ }^{*}$ A. J. Heinrichs,${ }^{* 2}$ C. M. Jones, ${ }^{*}$ T. M. Hill, $†$ and J. D. Quigley† \\ *The Pennsylvania State University, University Park 16802 \\ †Provimi North America, Brookville, OH 45309
}

\begin{abstract}
A series of 3 trials was conducted to determine effects of whole or ground oats in starter grain on reticulorumen fermentation and digestive system development of preweaned calves. Male Holstein calves $(43.1 \pm 2.3$ $\mathrm{kg}$ at birth; $\mathrm{n}=8,9$, and 7 for trials 1,2 , and 3 , respectively) were housed in individual pens in a heated facility; bedding was covered with landscape fabric to prevent consumption of bedding by the calves. In trials 1 and 2 only, calves were fitted with rumen cannulas by wk 2 of life. In all trials, a fixed amount of starter (containing $25 \%$ oats either ground and in the pellet or whole) was offered daily; orts were fed through the cannula in trials 1 and 2 . Calves were randomly assigned to an all-pelleted starter or pellets plus whole oats. Rumen contents (trials 1 and 2) were sampled weekly at -8 , $-4,0,2,4,8$, and $12 \mathrm{~h}$ after grain feeding for determination of $\mathrm{pH}$ and volatile fatty acids. Calves were killed 3 wk (trial 1) or 4 wk (trials 2 and 3) after grain was offered; organs were harvested, emptied, rinsed, and weighed to gauge digestive organ development. Starter intake was not different between treatments. Weekly measurements of rumen digesta $\mathrm{pH}$ did not change and only subtle changes were observed in molar proportions of individual volatile fatty acids. Molar proportion of butyrate and $\mathrm{pH}$ linearly decreased with age, whereas acetate proportion increased. Reticulorumen weight and papillae length tended to be greater for calves fed pelleted starter, whereas abomasum weight was greater for calves fed pellets plus whole oats. Fecal particle size and starch content were greater for calves fed pellets plus whole oats. Under the conditions of this study, physical form of oats in starter grain did not affect rumen fermentation measurements; greater rumen weight and papillae length in calves fed pelleted starter may be the result of greater nutrient availability of ground

\footnotetext{
Received December 4, 2014.

Accepted January 21, 2015.

${ }^{1}$ This research was a component of NC-2042: Management Systems

${ }^{2}$ Corresponding author: ajh@psu.edu
} to Improve the Economic and Environmental Sustainability of Dairy Enterprises.
\end{abstract}

oats. Under the conditions of this study with young calves on treatments for $<4 \mathrm{wk}$, increasing particle size of the starter by feeding whole oats did not affect rumen fermentation nor did it improve digestive system development.

Key words: calf, rumen fermentation, whole oat

\section{INTRODUCTION}

A large variety of feedstuffs can be fed to neonatal dairy calves. In addition to diverse nutritive values, feed sources can be offered in various forms to provide differing physical and digestive functions in calf starters. The National Research Council (NRC, 2001) suggests that calves be restrained from eating long hay before weaning but recommends provision of feed with sufficient coarseness to avert impaction of particles between rumen papillae and prevent abnormal growth of papillae. Previous studies have shown that diets in which all ingredients were ground increased papillae keratinization and incidence of abnormal shape compared with diets with a greater particle size (Greenwood et al., 1997; Beharka et al., 1998). Feeding starter in a coarse mash form versus ground and pelleted increased DM digestibility at $8 \mathrm{wk}$ of age, reduced the age at which calves started ruminating and increased time spent ruminating (Porter et al., 2007). Increasing time spent ruminating increases saliva production, which increases buffering capacity in the rumen (Krause and Oetzel, 2006). Higher rumen $\mathrm{pH}$ in response to greater particle size has been observed in diets containing hay (Greenwood et al., 1997; Beharka et al., 1998). Effects of particle size in calf starters on rumen fermentation have been previously studied, but starters contained hay (Greenwood et al., 1997; Beharka et al., 1998), calves were not prevented from consuming bedding (Lesmeister and Heinrichs, 2004), or fermentation was measured only at slaughter (Porter et al., 2007). Hay in the starter and consumption of bedding materials are confounding factors when assessing effects of grain particle size. Whole oats are approximately $10.27 \mathrm{~mm}$ in length (Doehlert et al., 2006), which is greater than the threshold particle size for particles leaving the ru- 
men in adult cattle and sheep (Maulfair et al., 2011). Thus, whole oats must be broken down mechanically by chewing, which should increase time spent chewing and slow the rate at which oat starch is available to rumen microbes, resulting in a more stable rumen environment and providing the necessary abrasion to prevent the buildup of keratin on the rumen epithelium.

The objective of this study was to evaluate whether increasing the particle size of calf starter by providing whole oats would affect rumen $\mathrm{pH}$, rumen fermentation, and development of the digestive system. A secondary objective was to observe rumen fermentation at an early age. We hypothesized that whole versus ground oats in the starter would increase rumen development by providing a longer feed particle size that would improve digestion and rumen papillae growth.

\section{MATERIALS AND METHODS}

Protocols for this study were approved by The Pennsylvania State University Institutional Animal Care and Use Committee under IACUC \#41010. Three trials were done as part of this experimental protocol.

In trial 1 , Holstein bull calves $(\mathrm{n}=10)$ purchased from a single commercial herd were removed from their dams after birth, weighed, and fed $3.6 \mathrm{~L}$ of colostrum within $1 \mathrm{~h}$ of birth. Calves were then transported for 20 min to the experimental housing facility, where they were fed an additional $1.8 \mathrm{~L}$ of colostrum 6 to $8 \mathrm{~h}$ after the first feeding. Housing consisted of individual pens $2.1 \times 1.6 \mathrm{~m}$ inside a mechanically ventilated, heated facility; bedding was covered with landscape fabric to avoid any consumption of bedding by calves. Water was offered free choice, and a medicated (decoquinate, 34 $\mathrm{mg} / \mathrm{kg}$ ) milk replacer powder containing $20 \% \mathrm{CP}$ and $20 \%$ fat (Provimi North America, Brookville, $\mathrm{OH}$ ) and reconstituted to $13 \% \mathrm{DM}$ was fed at $12 \%$ of birth BW divided in 2 equal feedings per day at 0800 and $1930 \mathrm{~h}$. All calves were ruminally fistulated with $28-\mathrm{mm}$ (i.d.) rubber cannulas by the second week of age, when they were randomly assigned to treatments: an all-pelleted starter with ground oats in the pellet $(\mathbf{G})$ or pellets plus whole oats (W; Table 1). Starters differed only in oats processing, with all ingredients coming from the same batch; a single batch of each starter was prepared and used for all 3 trials. Calf starter was fed once daily at $2000 \mathrm{~h}$, after feeding of the milk replacer. Amount of starter offered was adjusted by age and was based on average intakes of calves fed similar milk replacer diets. To equalize intake, calves were fed a fixed amount of starter; orts, when present, were placed in the rumen through the cannula at $2000 \mathrm{~h}$. Health was monitored twice daily, and sick calves were treated per veterinary recommendation.
Table 1. Ingredient and chemical composition and particle size of starters containing ground oats in a pelleted feed $(\mathrm{G})$ or whole oats plus a pellet $(\mathrm{W})$

\begin{tabular}{|c|c|c|}
\hline Item & $\mathrm{G}$ & $\mathrm{W}$ \\
\hline \multicolumn{3}{|c|}{ Ingredient composition, $\%$ of DM } \\
\hline Ground corn & 37.00 & 37.00 \\
\hline Ground oats $^{1}$ & 25.00 & - \\
\hline Whole oats $^{1}$ & - & 25.00 \\
\hline Soybean meal, $48 \% \mathrm{CP}$ & 24.46 & 24.46 \\
\hline Wheat middlings & 4.81 & 4.81 \\
\hline Dry molasses & 3.00 & 3.00 \\
\hline Fat & 2.00 & 2.00 \\
\hline Calcium carbonate & 0.78 & 0.78 \\
\hline Premix $^{2}$ & 0.75 & 0.75 \\
\hline Salt & 0.60 & 0.60 \\
\hline Monocalcium phosphate & 0.59 & 0.59 \\
\hline Decoquinate $6 \%$ & 0.50 & 0.50 \\
\hline Pellet binder & 0.50 & 0.50 \\
\hline \multicolumn{3}{|c|}{ Chemical composition, $\%$ of DM } \\
\hline $\mathrm{DM}$ & 88.07 & 87.66 \\
\hline $\mathrm{CP}$ & 18.95 & 18.39 \\
\hline Starch & 42.60 & 43.60 \\
\hline Fat & 4.91 & 4.83 \\
\hline $\mathrm{ADF}$ & 7.79 & 7.05 \\
\hline NDF & 12.30 & 13.14 \\
\hline Ash & 5.28 & 5.73 \\
\hline $\mathrm{Ca}$ & 0.80 & 0.77 \\
\hline $\mathrm{P}$ & 0.53 & 0.57 \\
\hline \multicolumn{3}{|l|}{ Particle size, mm } \\
\hline $\mathrm{X}_{\mathrm{gm}}$ retained $^{3}$ & 1.23 & 1.84 \\
\hline $\mathrm{S}_{\mathrm{gm}}$ retained $^{3}$ & 1.15 & 1.18 \\
\hline $\mathrm{X}_{\mathrm{gm}}$ total $^{4}$ & 0.58 & 0.91 \\
\hline $\mathrm{S}_{\mathrm{gm}}$ total $^{4}$ & 1.56 & 1.72 \\
\hline$\%$ particles $>1.18 \mathrm{~mm}^{5}$ & 41.00 & 65.78 \\
\hline
\end{tabular}

${ }^{1}$ Contained (\% of DM) 48.5 starch, 28.2 NDF.

${ }^{2}$ The premix contained (per kilogram) $160 \mathrm{~g}$ of $\mathrm{Cu}, 0.13 \mathrm{~g}$ of $\mathrm{Co}, 9.40$ $\mathrm{g}$ of Fe, $0.14 \mathrm{~g}$ of I, $5.4 \mathrm{~g}$ of Mn, $0.04 \mathrm{~g}$ of Se, $6.70 \mathrm{~g}$ of $\mathrm{Zn}, 1,800 \mathrm{IU}$ of vitamin A, $600 \mathrm{IU}$ of vitamin D, $16 \mathrm{IU}$ of vitamin E, $0.01 \mathrm{~g}$ of biotin, $2.93 \mathrm{~g}$ of cobalamin, $0.04 \mathrm{~g}$ of folic acid, $1.77 \mathrm{~g}$ of niacin, $1.32 \mathrm{~g}$ of pantothenic acid, $0.24 \mathrm{~g}$ of pyridoxine, $0.30 \mathrm{~g}$ of riboflavin, and $0.29 \mathrm{~g}$ of thiamin (Provimi North America, Brookville, OH).

${ }^{3}$ Geometric mean $\left(\mathrm{X}_{\mathrm{gm}}\right)$ and standard deviation $\left(\mathrm{S}_{\mathrm{gm}}\right)$ of particle length as calculated by ASABE (2007) using data from screens $\geq 0.15 \mathrm{~mm}$. Particles retained on the top screen were assumed to be $4.7 \mathrm{~mm}$ long. ${ }^{4}$ Geometric mean $\left(\mathrm{X}_{\mathrm{gm}}\right)$ and standard deviation $\left(\mathrm{S}_{\mathrm{gm}}\right)$ of particle length as calculated by ASABE (2007) using data from all particle fractions. Particles retained on the top screen were assumed to be $4.7 \mathrm{~mm}$ long. ${ }^{5}$ Cumulative proportion of particles retained on the $1.18-\mathrm{mm}$ sieve or above.

Rumen contents were sampled $1 \mathrm{~d} /$ wk starting $1 \mathrm{wk}$ after starter was offered at $-8,-4,0,2,4,8$, and 12 $\mathrm{h}$ after starter feeding. Contents (about $40 \mathrm{~mL}$ ) were strained through 2 layers of cheese cloth, and $\mathrm{pH}$ of the fluid fraction was immediately determined by using a hand-held $\mathrm{pH}$ meter (pHTestr 10, Eutech Instruments, Vernon Hills, IL). Rumen fluid ( $5 \mathrm{~mL}$ ) was then placed into tubes containing $1 \mathrm{~mL}$ of $25 \%$ metaphosphoric acid and $1 \mathrm{~mL}$ of $6 \%$ 2-ethyl butyric acid (internal standard) and stored at $-20^{\circ} \mathrm{C}$ until analyzed for VFA and $\mathrm{NH}_{3}$. Feces were collected from the landscape fabric over a 22 -h period at the time of rumen sampling and stored at $-20^{\circ} \mathrm{C}$ for later analysis. 
A xylose absorption test was conducted when grain feeding began and weekly thereafter. D-Xylose (Alfa Aesar, Ward Hill, MA) was administered in the morning milk replacer at $0.5 \mathrm{~g} / \mathrm{kg}$ of BW. Blood samples were collected before and $4 \mathrm{~h}$ post-xylose administration via jugular venipuncture into evacuated tubes sprayed with anticoagulant ( $\mathrm{K}_{2}$ EDTA; Becton, Dickinson and Company, Franklin Lakes, NJ). Blood was centrifuged at $3,600 \times g$ for $15 \mathrm{~min}$ and plasma was stored at $-20^{\circ} \mathrm{C}$ until analysis.

At 5 wk of age (3 wk of grain feeding), calves were killed via captive bolt stunning and exsanguination. Reticulorumens, omasums, and abomasums were collected, emptied, rinsed with cold water, drained of excess water, dissected, and weighed. Livers and spleens were collected, rinsed with cold water, drained of excess water, and weighed. Reticulorumen contents were strained through 2 layers of cheese cloth; the solid fraction was stored at $-20^{\circ} \mathrm{C}$ until analyzed for particle size. The small intestine was sampled at approximately $20 \mathrm{~cm}$ from the pylorus (duodenum), at its estimated midpoint (jejunum), and $20 \mathrm{~cm}$ from cecum (ileum); samples were immediately rinsed with ice-cold physiological saline and stored in $10 \%$ neutral buffered formalin (Azer Scientific Inc., Morgantown, PA).

In trial 2 , calves $(\mathrm{n}=10)$ were under the same management practices and measurements as in trial 1 with the exception that the trial was extended for $1 \mathrm{wk}$ so that calves were killed at $6 \mathrm{wk}$ of age, after $4 \mathrm{wk}$ of starter feeding. Milk replacer powder contained $20 \%$ $\mathrm{CP}$ and $20 \%$ fat and was medicated (decoquinate, 50 $\mathrm{mg} / \mathrm{kg}$; Renaissance Nutrition, Roaring Spring, PA). A subsample of feces $(10 \mathrm{~g})$ from every fecal deposition was immediately analyzed for $\mathrm{pH}$ after it was mixed in equal amounts (wt/wt) of distilled water.

In trial 3, calves $(\mathrm{n}=8)$ underwent the same management practices as in trial 1 , with the exceptions that calves were not fistulated, starter feeding began at $3 \mathrm{wk}$ of age, and calves were killed at $7 \mathrm{wk}$ of age (4 wk of starter feeding). Milk replacer powder contained $20 \%$ $\mathrm{CP}$ and $20 \%$ fat (US Feeds, Eldora, IA), and decoquinate (Deccox-M; Alpharma, Bridgewater, NJ) was added to milk replacer at about $35 \mathrm{mg} / \mathrm{kg}$. Feces were analyzed for $\mathrm{pH}$ as in trial 2 .

\section{Sample Analyses}

Samples of manufactured pellets were collected from every second bag $(22.7 \mathrm{~kg})$ at the time of manufacturing and composited, before whole oats and pellets were mixed for the $\mathrm{W}$ starter. Pellet samples and whole oats were analyzed (AOAC International, 2000) for DM (oven method 930.15), ash (oven method 942.05), CP (Kjeldahl method 988.05), fat (diethyl ether ex- traction method 2003.05), and Ca and P (dry ashing, acid digestion, analysis by inductively coupled plasma spectroscopy; method 985.01). Additionally, NDF with ash concentration by the procedure of Van Soest et al. (1991) without sodium sulfite or $\alpha$-amylase, and ADF with ash concentration (Robertson and Van Soest, 1981) were quantified. Starch was analyzed with correction for free glucose as described in Hall (2009). A portion of each fecal sample was dried in a forced air oven at $55^{\circ} \mathrm{C}$ for $72 \mathrm{~h}$ to determine $\mathrm{DM}$ and starch content. Feces were gelatinized with sodium hydroxide for starch concentration analysis by Karkalas (1985) enzymatic method.

The concentration of xylose in plasma was analyzed as described by Merritt and Duelly (1983); absorption was calculated by the difference before and after xylose administration. After thawing, rumen fluid was centrifuged 3 times at $4,000 \times g$ for $30 \mathrm{~min}$ at $4^{\circ} \mathrm{C}$ to obtain a clear supernatant, which was analyzed for $\mathrm{NH}_{3}$ according to Chaney and Marbach (1962). Supernatant was filtered through a $0.45-\mu \mathrm{m}$ polypropylene membrane before being analyzed for VFA molar concentration by gas chromatography (Yang and Varga, 1989).

Particle size distribution of feces and the solid fraction of reticulorumen contents was analyzed via the wet-sieving technique of Maulfair and Heinrichs (2010), using screens with nominal size openings of $0.15,0.425$, $0.6,0.85,1.0,1.18$, and $3.35 \mathrm{~mm}$ (VWR, Arlington Heights, IL). Starters were submerged in hot water for 10 min before sieving. The fraction that passed through the $0.15-\mathrm{mm}$ screen was considered soluble. Data were analyzed considering the percentage of DM of each particle fraction retained on screens $\geq 0.15 \mathrm{~mm}$ (retained) and including the soluble fraction (total). Geometric mean particle length $\left(\mathbf{X}_{\mathbf{g m}}\right)$ was calculated (ASABE, 2007) with particles retained on the top screen assumed to be $4.7 \mathrm{~mm}$ long (square-hole diagonal of top screen) as done in Maulfair and Heinrichs (2010).

Reticulorumen dissection and measurement of rumen papillae and wall thickness followed Lesmeister et al. (2004; five $1-\mathrm{cm}^{2}$ samples collected from each of 9 areas) with 8 papillae measured per sample (40/area) and rumen wall thickness measured twice per sample (10/area). Formalin-fixed intestinal samples and a sample from the left side of the cranial ventral sac of the rumen were embedded in paraffin, sliced, and stained with hematoxylin and eosin. Villus length and crypt depth of intestinal samples were evaluated using a measuring reticule fitted on the eyepiece; mean villus height and crypt depth came from 20 well-oriented crypt-villus units from each intestinal section. Papillae shape and keratin layer were determined in rumen slides. A 0 to 5 scale, with 0 being nonexistent and 5 maximum thickness, was used for the keratin layer. 
Each calf was categorized as having either normal or abnormal papillae based on the shape of the majority of papillae; blunted and arborized papillae were considered abnormal, whereas tongue-shaped papillae were considered normal.

\section{Statistical Analyses}

Data were analyzed using the MIXED procedure in SAS (version 9.4; SAS Institute Inc., Cary, NC) as a completely randomized block design with trial as block. Calf within treatment was a random effect used to test the fixed effect of treatment, block was a fixed effect, and interaction between block and treatment was tested in the model. Fixed effect of time and its interactions with other fixed effects were included in the model when multiple observations occurred between weeks (day for intake) and within sampling day. Repeated measures using a heterogeneous, compound symmetry covariance structure were used for fecal $\mathrm{pH}$ and fecal starch; variance components covariance structure was used for fecal particle size and xylose data; and autoregressive variance components covariance structure for intake. Goodness of fit criteria were used to select covariance structures for variables. Packed cell volume (\%) was tested as a covariate for xylose absorption but not included because it was not significant. Spatial (power) covariance structure $[\mathrm{SP}(\mathrm{POW})]$ was used for rumen fermentation data because of unequally spaced data; the distance between sampling points over the day was uneven. Linear and quadratic contrasts for time after grain feeding between weeks and within sampling day were tested using the CONTRAST statement. Chisquared with the Fisher exact test was used to analyze papillae shape. Least squares means are presented in tables, and evidence for statistical significance was declared at $P \leq 0.05$ with trends at $0.05<P<0.10$.

\section{RESULTS AND DISCUSSION}

One calf from trial 1 was eliminated from data analysis because of excessive leaking from the rumen fistula; 2 calves were eliminated from trials 1 and 3 due to scours; and 1 calf in trial 2 died from peritonitis. The number of calves used for analyses in each trial is reported in Table 2. Ingredient composition of starter grain (Table 1) differed only in oats processing, and chemical composition was similar between diets. The processing of oats influenced the particle size of starters; the proportion of particles on the top sieve for $\mathrm{W}$ was greater, as expected, compensated for by a lower proportion in the soluble fraction. When combined, these changes made $\mathrm{X}_{\mathrm{gm}}$ of $\mathrm{W}$ about $50 \%$ larger than that of $\mathrm{G}$. The proportion of particles $>1.18 \mathrm{~mm}$ in $\mathrm{G}$
Table 2. Description of calves fed starters containing ground oats in a pelleted feed $(\mathrm{G})$ or whole oats plus a pellet $(\mathrm{W})$

\begin{tabular}{lcccc}
\hline & \multicolumn{4}{c}{ Diet } \\
\cline { 2 - 3 } Item & $\mathrm{G}$ & $\mathrm{W}$ & SEM & \\
\hline Calves, no. & & & & \\
$\quad$ Trial 1 & 4 & 4 & - & - \\
Trial 2 & 4 & 5 & - & - \\
Trial 3 & 3 & 4 & - & - \\
BW at birth, kg & 43.3 & 42.8 & 0.7 & 0.58 \\
BW at slaughter, kg & 60.4 & 59.4 & 1.3 & 0.57 \\
\hline
\end{tabular}

was lower than the recommended particle size $(50 \%$ of particles $>1.19 \mathrm{~mm}$ ) for calves fed starter with no forage and without access to consume bedding to ensure adequate intake and proper rumen fermentation (Warner et al., 1973), prevent physiological abnormalities, and initiate rumination (Porter et al., 2007). The proportion of DM with particles $>1.18 \mathrm{~mm}$ in $\mathrm{W}$ was $60 \%$ greater than that of $\mathrm{G}$; hence, particle size was expected to have a large effect on rumen fermentation and rumen development measurements.

Total starter intake (voluntary intake plus orts put through the cannula, Figure 1) was similar between treatments and increased with time, by design. The distance between voluntary intake and total intake increased by day and was likely in response to the amount of starter put through the cannula. Figure 2 compares voluntary intake between trials. From 1 to $21 \mathrm{~d}$, no difference was detected between trials, but between 22 and 28 d, voluntary intake of noncannulated calves (trial 3) increased, whereas that of cannulated calves decreased (trial 2). Voluntary intake (Figure 1) was affected by intake in trial 3 , in which calves were not cannulated, so the decline observed in Figure 2 for trial 2 was not detected and instead voluntary intake seemed to be somewhat level up to $27 \mathrm{~d}$. The intake decrease on d 21 was because calves in trial 1 were harvested on d 22, so time for voluntary intake was reduced and no starter was put through the cannula. Likewise, there are no data for total intake on d 28 and voluntary intake declined. Because total intake for cannulated calves between treatments was equal, the distance between treatments after $21 \mathrm{~d}$ comes from trial 3 , where, although intake was not different $(P>0.1)$, calves on $\mathrm{G}$ had greater intake $( \pm \mathrm{SEM})$ than calves on $\mathrm{W}(658 \pm 63$ vs. $567 \pm 54 \mathrm{~g} / \mathrm{d})$. Intake disparities in trial 3 did not affect rumen fermentation measurements because calves in that trial were not cannulated.

\section{Rumen Fermentation}

Rumen $\mathrm{pH}$ was not affected by diet and decreased linearly with age (Table 3 ). The decline in rumen $\mathrm{pH}$ 


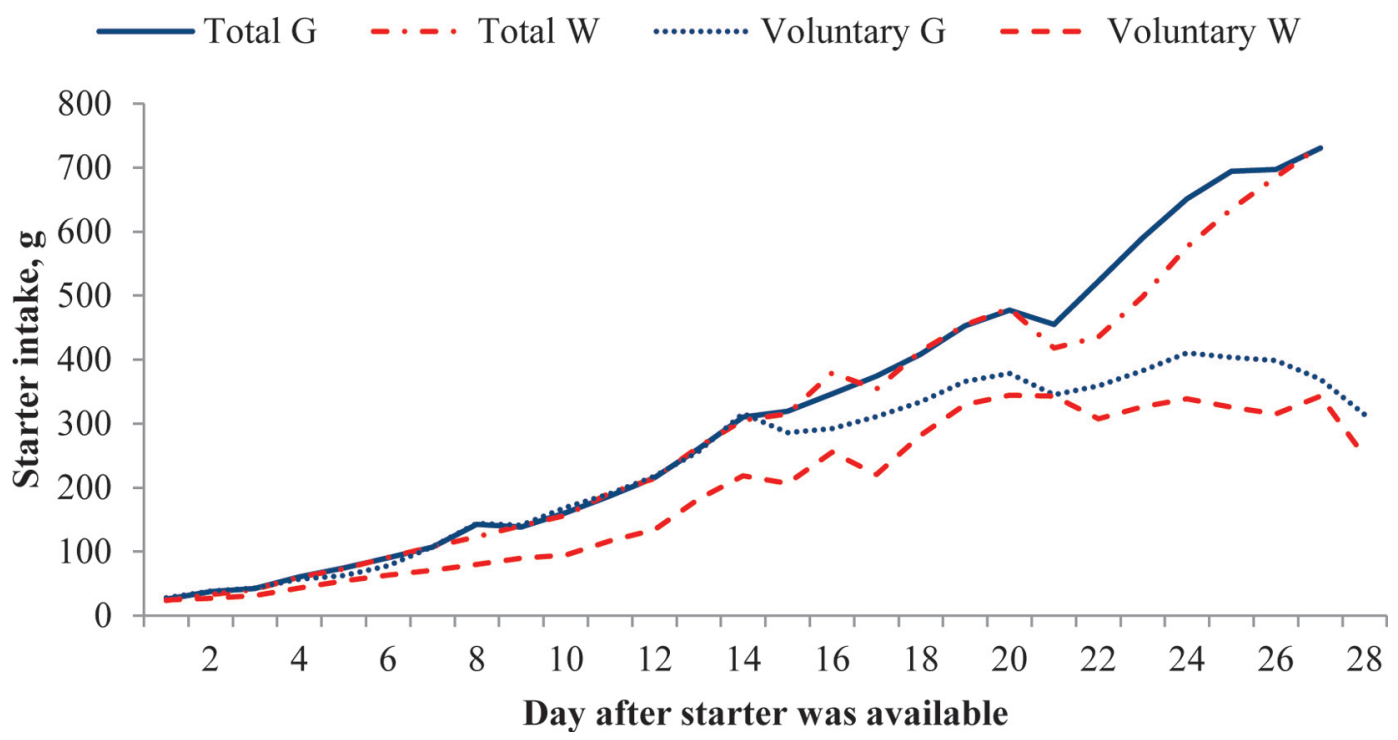

Figure 1. Starter intake of calves fed ground $(\mathrm{G})$ or whole $(\mathrm{W})$ oats in the starter. Data come from 3 trials with 8,9 , and 7 calves for trials 1,2 , and 3, respectively. Calves in trials 1 and 2 were fitted with rumen cannulas, and calves in trial 1 were slaughtered on d 22 . Total starter intake $(\mathrm{T})$ is voluntary intake $(\mathrm{V})$ plus starter introduced through rumen cannulas. No effect of diet was detected for voluntary intake $(P=0.18)$ or total intake $(P=0.19)$. Color version available online.

with age is consistent with the Beharka et al. (1998) study, where $\mathrm{pH}$ decreased until wk 8 of age. This decrease in $\mathrm{pH}$ with age is a response of increased starter intake. Figure 3 illustrates $\mathrm{pH}$ variation over time after grain feeding; a nadir is reached at approximately $4 \mathrm{~h}$ after feeding for wk 1 to 3 and at $8 \mathrm{~h}$ for wk 4 . By 2 $\mathrm{h}$ postprandium $(\mathbf{P P})$, rumen $\mathrm{pH}$ was reduced by approximately $1.5 \mathrm{pH}$ units in wk 2 and 3 and 1 unit in wk 4 , which is an increase in acidity of $42,57,30$, and 10 times (Covington et al., 1985) compared with preprandial levels for wk 1 through 4 respectively. The 2 -h PP increase in acidity decreased with age even when starch intake at sampling day increased from about $50 \mathrm{~g}$ in wk 1 to 124,217 , and $325 \mathrm{~g}$ in wk 2,3 , and 4, respectively. This is likely because rumen fluid buffering capacity increases with age and, at low $\mathrm{pH}$ levels, VFA contribute to rumen buffering (Williams and Frost, 1992). However, the dramatic change in acidity likely affected microbial populations (particularly pH-sensitive microflora such as cellulolytic fermenters; Slyter, 1986; Anderson et al., 1987), morphological changes in epithelial structure (Steele et al., 2009, 2011a), and expression of genes involved in short-chain fatty acid metabolism and cholesterol homeostasis in the rumen epithelium (Steele

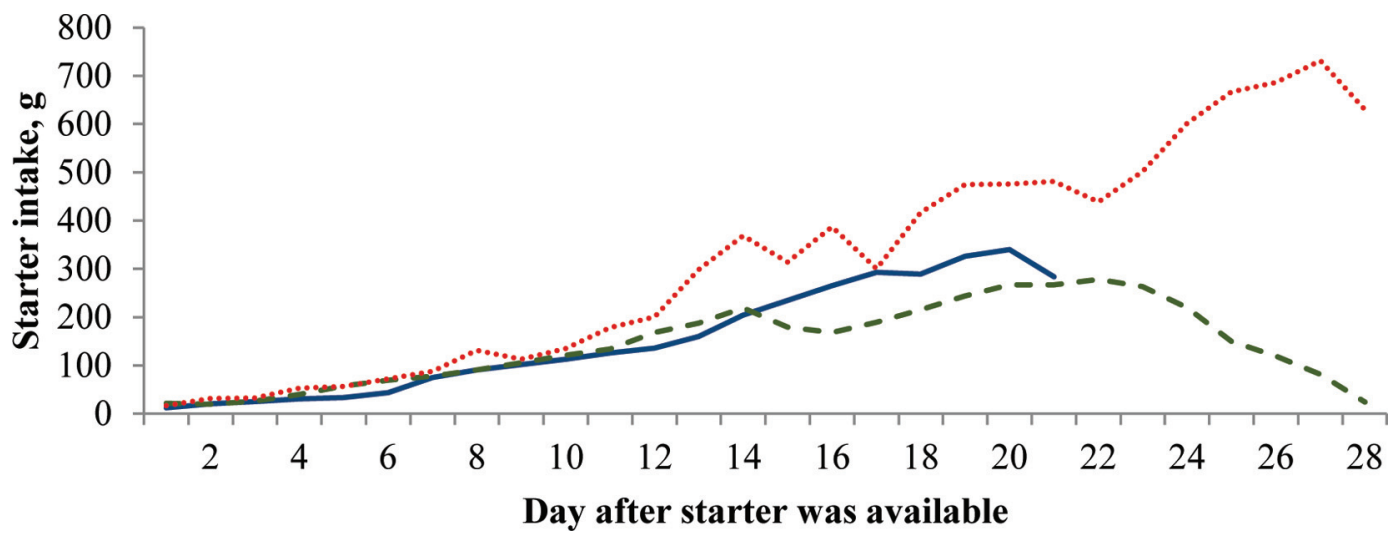

Figure 2. Mean voluntary starter intake of calves fed ground or whole oats in starter. Data come from 3 trials with 8,9 , and 7 calves for trials $1(-), 2(--)$, and $3(\cdots)$, respectively. Calves in trials 1 and 2 were fitted with rumen cannulas, and orts from their daily starter allotment were put through the cannula, that starter is not reflected in this figure. No effect of trial was detected up to d $21(P=0.25)$ or from d 22 to $28(P=0.32)$; no interaction was detected between trial and diet. Color version available online. 
et al., 2011b). During wk 4, pH was $<5.5$ most of the time and $<5$ for over $10 \mathrm{~h} / \mathrm{d}$, which in adult cattle is considered indicative of acute ruminal acidosis and can lead to fatal consequences (Krause and Oetzel, 2006). Calves in this study did not show signs of metabolic disorders, suggesting that calves at this age tolerate $\mathrm{pH}$ levels that would be detrimental for adult cattle health. A possible explanation for this resilience is that the rumen of the young calf in relation to its body size is smaller than in adult cattle and its capacity for absorption has not fully developed. Hence, the production and absorption of endotoxins that negatively affect adult cattle affected by acidosis, as described in a review by Plaizier et al. (2012), is not enough to compromise calf health. If absorptive capacity depended only on papillae length, calves in this study would have had just 10 to $14 \%$ of the absorptive capacity of an adult animal. Papillae length averaged $0.71 \pm 0.03 \mathrm{~mm}$ compared with a maximum length in mature cattle of between 5 and $7 \mathrm{~mm}$ (Huber, 1969). Nevertheless, potential carryover effects of low $\mathrm{pH}$ on later productivity and health cannot be determined from this study. It should be noted that the possibility exists that low $\mathrm{pH}$ may be beneficial to rumen development, as low $\mathrm{pH}$ might stimulate rumen epithelial cell proliferation (Laarman et al., 2012). The $\mathrm{pH}$ in wk 4 was lower than that reported previously (Beharka et al., 1998; Lesmeister and Heinrichs, 2004; Khan et al., 2008; Laarman et al., 2012), which might result from a combination of high starch levels and small particle size, lack of forage in the diet, and no access to bedding material for consumption in the present study. Feeding orts through the cannula may also have contributed to low $\mathrm{pH}$, as voluntary intake decreased with time, and orts were introduced once a day only, which may have overwhelmed rumen buffering capacity. Starter introduced through the cannula was not chewed, so it did not contribute to the flow of saliva to the rumen. This may have further reduced buffering capacity, as saliva contains large amounts of buffering compounds (Krause and Oetzel, 2006). The lack of differences in rumen $\mathrm{pH}$ between treatments is contrary to our hypothesis. We expected $\mathrm{W}$ to have a more consistent $\mathrm{pH}$ than $\mathrm{G}$ because of its greater particle size and slower fermentation of starch in the rumen. Greenwood et al. (1997) found that the greater particle size of starter resulted in higher rumen $\mathrm{pH}$, possibly via an increase in the time calves spent ruminating as particle size increased (Hodgson, 1971), thereby affecting saliva production and rumen buffering (Krause and Oetzel, 2006). Calves eating a starter with whole corn had higher $\mathrm{pH}$ than those fed processed corn (Lesmeister and Heinrichs, 2004). Whole oats need to be chewed for their starch to be available, which would decrease rumen-available starch at the time of eating. Particle size of rumen contents at slaughter (Table 4) 12 to 16 $\mathrm{h}$ after grain feeding was greater for $\mathrm{W}$, showing that some oats had not been broken down by chewing, and suggesting that the lack of effects in rumen $\mathrm{pH}$ in spite of differences in particle size could be due to particle size effects being overshadowed by high starch content of starters. Oats accounted for about $31 \%$ of total starch in starter, and oats starch for about $12 \%$ of starter DM. Corn processing affected rumen $\mathrm{pH}$ in the Lesmeister and Heinrichs (2004) study when it accounted for $33 \%$ of starter DM and about $75 \%$ of the $31 \%$ starch in the starter (assuming corn contained 70\% starch). Thus, it is possible that in the present study, the 31 percentage units of starch in starter provided by the pellets in $\mathrm{W}$ diet overwhelmed the effects of whole oats.

Low rumen $\mathrm{pH}$ is, in part, a consequence of acid production exceeding the capacity of absorptive mechanisms to clear VFA from the rumen, buffering capacity (particularly saliva produced during cud chewing), and outflow of acids from the rumen. Rapid fermentation of starches and sugars in starters clearly overwhelmed the limited ability of these neonates to maintain rumen $\mathrm{pH}$. Although there were no visible consequences of acute acidosis that occurred in the rumens of these calves, the long-term effects of continuous low rumen $\mathrm{pH}$ in calves are yet to be determined. In adult cattle, acidosis has long-term consequences, including laminitis and abscesses in the kidneys, liver, heart, and lungs, and it has been related to bacterial pneumonia (Kleen et al., 2003).

Total rumen VFA concentration did not differ by diet, but we detected a diet by week interaction, in which $\mathrm{G}$ tended to have higher VFA concentration in wk 2. The effect of starter particle size on rumen VFA is inconsistent; some researchers have observed greater VFA concentration with smaller particle size (Beharka et al., 1998; Coverdale et al., 2004), whereas others have not detected a difference (Greenwood et al., 1997). The quadratic effect of age on total VFA observed in this study differs from other studies in which VFA concentration increased continually to the end of the trial at $10 \mathrm{wk}$ (Anderson et al., 1987), 8 wk (Beharka et al.,1998), and 6 wk (Lesmeister and Heinrichs, 2004). The lower VFA concentration at wk 4 compared with wk 3 might be related to calves having a more mature rumen epithelium capable of absorbing more VFA or a faster rumen turnover rate. We assumed that VFA production would be greater in wk 4 due to greater starter intake. Greater VFA absorption capacity with age is also supported by the change in concentration between 2 and $4 \mathrm{~h}$ PP (Figure 4); VFA concentration between 2 and $4 \mathrm{~h} \mathrm{PP}$ went from no change at wk 1 and 2 to decreases of about 2 and $7 \%$ at 3 and $4 \mathrm{wk}$, respectively. Lower rumen VFA concentration at wk 4 
Table 3. Rumen fermentation of calves fed starters containing ground oats in a pelleted feed (G) or whole oats plus a pellet (W)

\begin{tabular}{|c|c|c|c|c|c|c|c|c|c|c|c|c|c|}
\hline \multirow[b]{3}{*}{ Item } & \multirow[b]{3}{*}{ Diet } & \multirow{2}{*}{\multicolumn{8}{|c|}{ Week $^{1}$}} & \multicolumn{4}{|c|}{$P$-value } \\
\hline & & & & & & & & & & \multirow[b]{2}{*}{ Diet } & \multirow{2}{*}{$\begin{array}{c}\text { Diet } \times \\
\text { week }\end{array}$} & \multicolumn{2}{|c|}{ Week } \\
\hline & & 1 & SEM & 2 & SEM & 3 & SEM & 4 & SEM & & & Linear & Quadratic \\
\hline \multirow[t]{2}{*}{ Calves, no. } & G & 8 & - & 8 & - & 8 & - & 4 & - & & & & \\
\hline & W & 9 & - & 9 & - & 9 & - & 5 & - & & & & \\
\hline \multirow[t]{2}{*}{ Rumen pH } & G & 6.26 & 0.14 & 5.57 & 0.14 & 5.53 & 0.13 & 4.91 & 0.18 & 0.85 & 0.41 & $<0.01$ & 0.90 \\
\hline & W & 6.05 & 0.13 & 5.66 & 0.13 & 5.43 & 0.13 & 5.01 & 0.16 & & & & \\
\hline \multirow{2}{*}{ Rumen $\mathrm{NH}_{3}, \mathrm{mg} / \mathrm{dL}$} & G & 5.68 & 0.90 & 5.18 & 0.88 & 5.87 & 0.88 & 4.68 & 1.06 & 0.26 & 0.02 & 0.02 & 0.14 \\
\hline & W & 5.88 & 0.85 & 3.78 & 0.83 & 2.87 & 0.83 & 3.86 & 0.98 & & & & \\
\hline \multirow[t]{2}{*}{ Total VFA, mM } & G & 63.74 & 8.61 & 107.50 & 8.50 & 99.96 & 8.60 & 76.77 & 9.65 & 0.31 & 0.07 & $<0.01$ & $<0.01$ \\
\hline & W & 49.63 & 8.13 & 84.08 & 8.03 & 90.57 & 8.11 & 77.71 & 8.97 & & & & \\
\hline \multirow{3}{*}{$\begin{array}{l}\text { Individual VFA, mol/100 mol } \\
\text { Acetate }\end{array}$} & & & & & & & & & & & & & \\
\hline & G & 62.78 & 2.30 & 62.39 & 2.26 & 67.94 & 2.25 & 76.85 & 2.70 & 0.80 & 0.08 & $<0.01$ & $<0.01$ \\
\hline & W & 60.50 & 2.18 & 66.96 & 2.14 & 67.60 & 2.13 & 77.70 & 2.50 & & & & \\
\hline \multirow[t]{2}{*}{ Propionate } & G & 20.42 & 1.78 & 23.45 & 1.74 & 23.84 & 1.73 & 18.02 & 2.11 & 0.95 & 0.12 & $<0.01$ & $<0.01$ \\
\hline & W & 23.13 & 1.68 & 22.51 & 1.65 & 21.66 & 1.64 & 17.91 & 1.95 & & & & \\
\hline \multirow[t]{2}{*}{ Butyrate } & G & 14.28 & 1.75 & 11.90 & 1.74 & 5.56 & 1.74 & 3.12 & 1.92 & 0.64 & $<0.01$ & $<0.01$ & 0.46 \\
\hline & W & 12.49 & 1.65 & 8.18 & 1.65 & 7.93 & 1.65 & 1.99 & 1.80 & & & & \\
\hline \multirow[t]{2}{*}{ Valerate } & G & 0.97 & 0.19 & 1.52 & 0.19 & 1.74 & 0.19 & 1.35 & 0.23 & 0.68 & 0.05 & 0.12 & $<0.01$ \\
\hline & W & 1.45 & 0.18 & 1.34 & 0.18 & 1.88 & 0.18 & 1.27 & 0.21 & & & & \\
\hline \multirow[t]{2}{*}{ Isovalerate } & G & 0.81 & 0.11 & 0.53 & 0.11 & 0.56 & 0.11 & 0.64 & 0.14 & 0.50 & $<0.01$ & $<0.01$ & $<0.01$ \\
\hline & W & 1.33 & 0.11 & 0.58 & 0.10 & 0.55 & 0.10 & 0.44 & 0.13 & & & & \\
\hline \multirow[t]{2}{*}{ Isobutyrate } & G & 0.63 & 0.08 & 0.37 & 0.08 & 0.35 & 0.08 & 0.31 & 0.10 & 0.86 & 0.33 & $<0.01$ & $<0.01$ \\
\hline & W & 0.77 & 0.08 & 0.37 & 0.08 & 0.34 & 0.08 & 0.26 & 0.09 & & & & \\
\hline
\end{tabular}

을 
Table 4. Rumen contents particle size of calves fed starters containing ground oats in a pelleted feed $(\mathrm{G})$ or whole oats plus a pellet (W)

\begin{tabular}{|c|c|c|c|c|c|}
\hline \multirow[b]{2}{*}{ Item } & \multicolumn{4}{|c|}{ Diet } & \multirow[b]{2}{*}{$P$-value } \\
\hline & G & SEM & W & SEM & \\
\hline Calves, no. & 11 & - & 13 & - & \\
\hline $\mathrm{X}_{\mathrm{om}}$, retained $^{1}$ & 1.04 & 0.10 & 1.90 & 0.09 & $<0.01$ \\
\hline $\mathrm{S}_{\mathrm{gm}}$, retained $^{1}$ & 1.15 & 0.01 & 1.21 & 0.01 & $<0.01$ \\
\hline \multicolumn{6}{|c|}{ Retained, \% of DM } \\
\hline $3.35-\mathrm{mm}$ sieve & 9.08 & 2.39 & 39.66 & 2.19 & $<0.01$ \\
\hline 1.18-mm sieve & 15.19 & 1.16 & 15.35 & 1.07 & 0.92 \\
\hline 1.00-mm sieve & 7.70 & 0.41 & 4.67 & 0.38 & $<0.01$ \\
\hline $0.85-\mathrm{mm}$ sieve & 6.16 & 0.27 & 3.80 & 0.24 & $<0.01$ \\
\hline $0.60-\mathrm{mm}$ sieve & 17.65 & 0.89 & 10.23 & 0.81 & $<0.01$ \\
\hline 0.425 -mm sieve & 17.06 & 0.71 & 9.77 & 0.65 & $<0.01$ \\
\hline 0.15 -mm sieve & 27.16 & 2.67 & 16.51 & 2.45 & 0.01 \\
\hline
\end{tabular}

${ }^{1}$ Geometric mean $\left(\mathrm{X}_{\mathrm{gm}}\right)$ and standard deviation $\left(\mathrm{S}_{\mathrm{gm}}\right)$ of particle length as calculated by ASABE (2007) using data from screens $\geq 0.15 \mathrm{~mm}$. Particles retained on the top screen were assumed to be $4.7 \mathrm{~mm}$ long.

along with lower $\mathrm{pH}$ implies that factors other than VFA concentration were influencing $\mathrm{pH}$. Terré et al. (2013) reported a high correlation of VFA with $\mathrm{pH}$ at $\mathrm{pH}>5.1$, but not when $\mathrm{pH}$ was $<5.1$, and suggested that lactic acid may also be influencing $\mathrm{pH}$. In adult sheep, the intake of highly digestible carbohydrates resulted in low rumen $\mathrm{pH}$ values that were related to high lactic acid concentration (Briggs et al., 1957). Rumen Lactobacillus counts were reported to steadily increase with age to up to about 5 wk of age (Anderson et al., 1987). Rumen lactate concentration was not
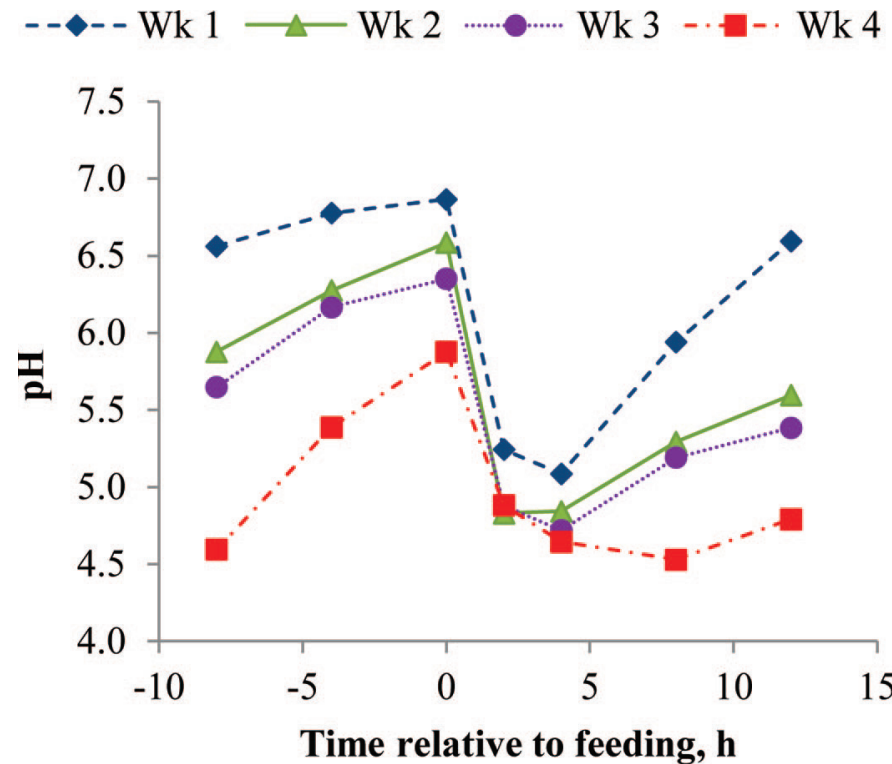

Figure 3. Mean rumen $\mathrm{pH}$ at $-8,-4,0,2,4,8$, and $12 \mathrm{~h}$ relative to feeding from 1 to $4 \mathrm{wk}$ after starter was available for calves fed ground or whole oats in the starter $(\mathrm{n}=17$ calves up to wk 3 and $\mathrm{n}$ $=9$ in wk 4$)$. Linear effect for week $(P<0.01)$, cubic effect for time relative to feeding $(P<0.01)$. Color version available online. measured in this study; however, the decrease in VFA concentration and $\mathrm{pH}$ in wk 4 suggest an increase in rumen lactic acid concentration. Molar proportions of acetate (Figure 5) increased with age, whereas those of propionate and butyrate decreased, which is the opposite of what has been reported previously (Anderson et al., 1987; Beharka et al., 1998), where acetate proportion decreased and propionate and butyrate increased. Conflicting results could be due to differences in diet composition and therefore rate of digestion, as starters contained 25\% alfalfa hay in those studies (Anderson et al., 1987; Beharka et al., 1998). However, lower fiber in this study compared with the Anderson et al. (1987) and Beharka et al. (1998) studies, accompanied by a decline in $\mathrm{pH}$ levels that would be detrimental to fiberdigesting bacteria (Slyter, 1986), suggests a decrease in acetate production. Therefore, the increase in acetate concentration with time was possibly responsive to changes in VFA absorption rate, which at low $\mathrm{pH}$ is greater for butyric acid, followed by propionic and then acetic acids (Weigand et al., 1972; Dijkstra et al., 1993). This is supported by changes in PP molar proportions of the 3 major VFA, more evidently with the changes at 4 wk. In this week, acetate proportion increased up to $8 \mathrm{~h} \mathrm{PP}$, the same sampling point at which propionate proportion and $\mathrm{pH}$ reached a nadir. Changes in butyrate concentration were subtle, and butyrate molar proportion was consistently under $5 \%$. Hence, differences in molar percentages of individual VFA with age between this study and the Anderson et al. (1987) and Beharka et al. (1998) studies were a result of lower rumen $\mathrm{pH}$ in this study. Similar PP changes in VFA molar proportions were reported in sheep fed diets high in starch, which depressed rumen $\mathrm{pH}$ below 5 (Reid et al., 1957). In this study, the only week in which $\mathrm{pH}$ was $>5$ at all times was wk 1 , and only in this week 


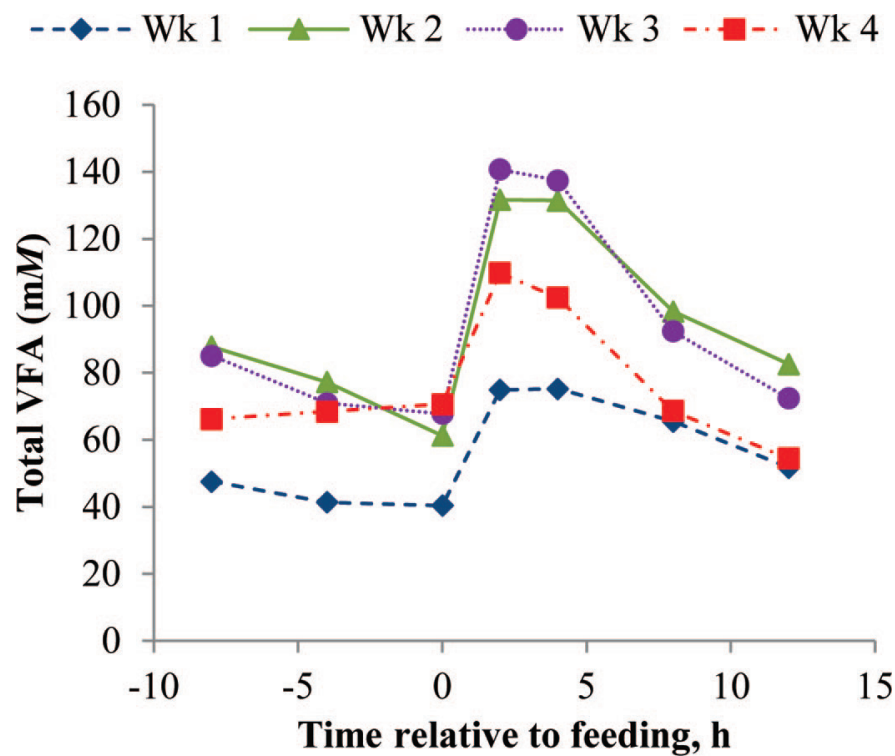

Figure 4. Mean rumen VFA concentrations at $-8,-4,0,2,4,8$, and $12 \mathrm{~h}$ relative to feeding from 1 to $4 \mathrm{wk}$ after starter was available for calves fed ground or whole oats in the starter $(\mathrm{n}=17$ calves up to wk 3 and $\mathrm{n}=9$ in wk 4$)$. Quadratic effect for week $(P<0.01)$, cubic effect for time relative to feeding $(P<0.01)$. Color version available online.

did the proportion of propionate increase while acetate decreased 2 h PP. Additionally, when $\mathrm{pH}$ of 16 -wk-old calves reached low levels PP but never below 5, acetate decreased while propionate and butyrate increased (Quigley et al., 1992). Altogether, high proportions of acetate observed in this experiment are a result of its accumulation, which can be expected at low pH levels, and does not mean that its rate of production was not reduced (Reid et al., 1957). Iso-acid molar proportions were low and decreased with calves' age, as in previous reports (Anderson et al., 1987; Beharka et al., 1998).

Rumen $\mathrm{NH}_{3}$ did not differ between diets, but we detected a diet $\times$ week interaction, in which $G$ had a higher concentration than $\mathrm{W}$ in wk 3 . Concentration of $\mathrm{NH}_{3}$ decreased with age, which is consistent with what Lesmeister and Heinrichs (2004) observed through wk 4, Beharka et al. (1998) through wk 8, and Anderson et al. (1987) through $12 \mathrm{wk}$ of age. In those studies, this change was attributed to an increased use of $\mathrm{NH}_{3}$ by the rumen microbial population. The PP slopes for rumen $\mathrm{NH}_{3}$ (Figure 6) are different from those reported by Quigley et al. (1992), where $\mathrm{NH}_{3}$ concentration increased after feeding. A PP decrease in $\mathrm{NH}_{3}$ concentration is not common, as microbial proteolytic activity usually results in an increased $\mathrm{NH}_{3}$ concentration after feeding. However, a PP decrease in rumen $\mathrm{NH}_{3}$ concentration was observed in steers fed diets high in steamflaked corn with $49 \%$ dietary starch concentration

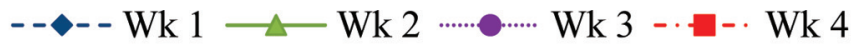
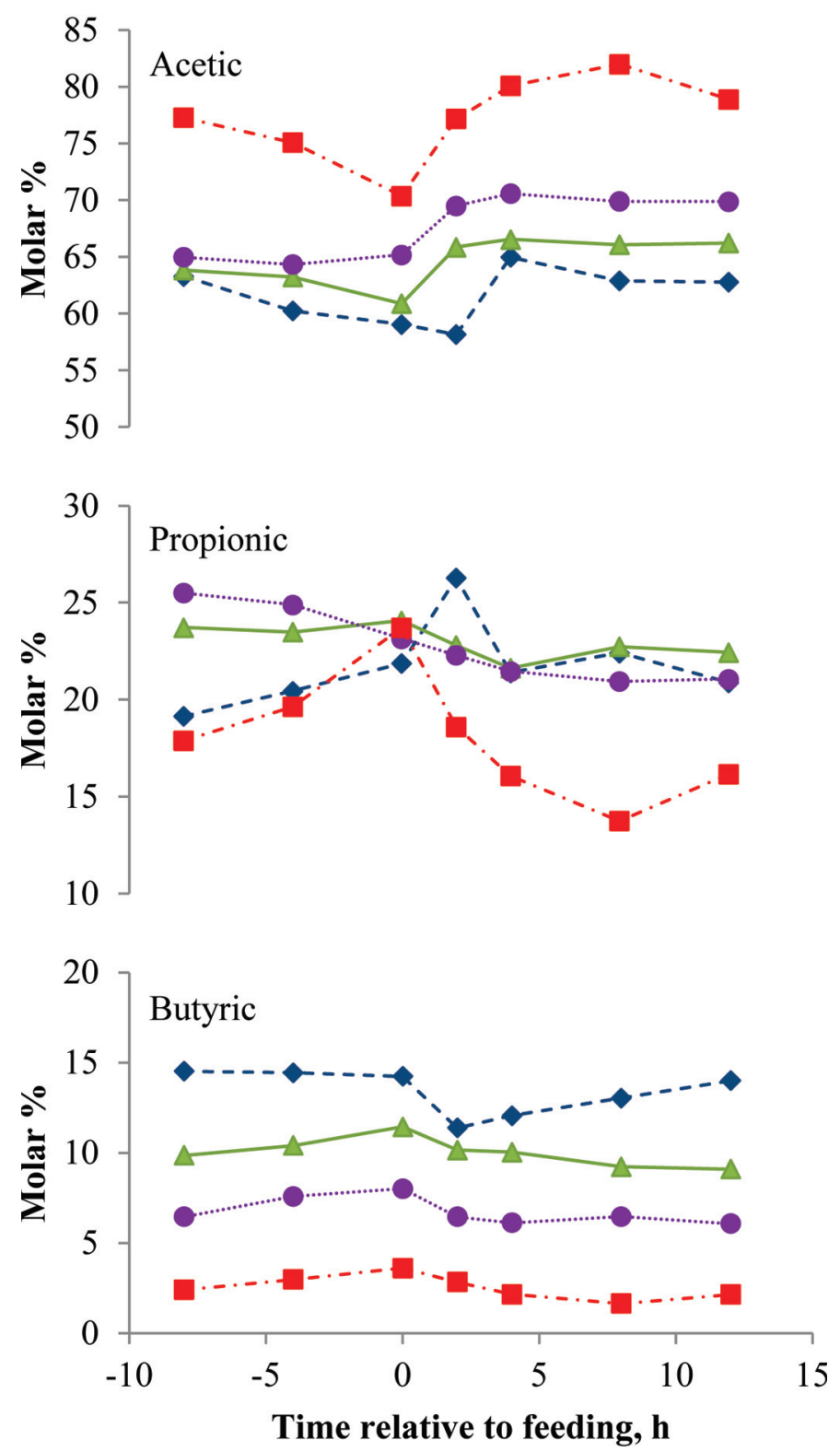

Figure 5. Mean rumen acetate, propionate, and butyrate molar percentages of total VFA at $-8,-4,0,2,4,8$, and $12 \mathrm{~h}$ relative to feeding for wk 1 to 4 after starter was available for calves fed ground or whole oats in the starter $(\mathrm{n}=17$ calves up to wk 3 and $\mathrm{n}=9$ in wk 4). Acetate and butyrate cubic effects for time relative to feeding $(P<$ $0.05)$; propionate effect for time relative to feeding: linear $(P=0.06)$ and cubic $(P=0.15)$ effects. Color version available online.

(Uwituze et al., 2010). In the same study, diets with about $65 \%$ starch did not show a $\mathrm{PP}$ rumen $\mathrm{NH}_{3}$ decrease $2 \mathrm{~h}$ after feeding, but those diets had $>1 \%$ NPN (urea) as an ingredient, which likely affected rumen $\mathrm{NH}_{3}$ concentration. The decrease in rumen $\mathrm{NH}_{3}$ may be partly related to low rumen $\mathrm{pH}$, because protein deg- 


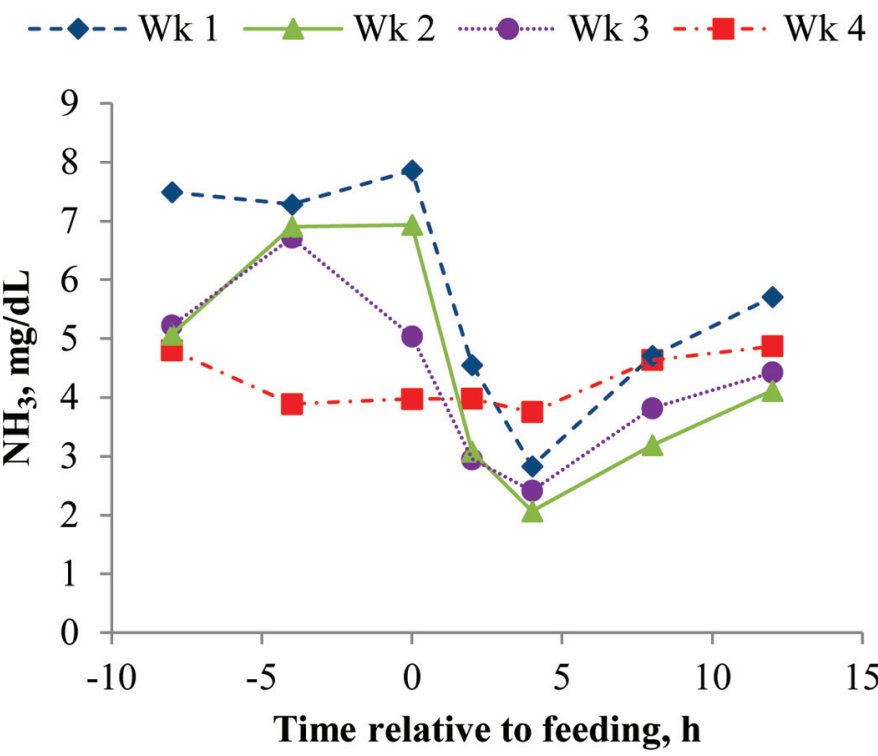

Figure 6. Mean rumen $\mathrm{NH}_{3}$ concentration at $-8,-4,0,2,4,8$, and $12 \mathrm{~h}$ relative to feeding from 1 to $4 \mathrm{wk}$ after starter was available for calves fed ground or whole oats in the starter $(\mathrm{n}=17$ calves up to wk 3 and $\mathrm{n}=9$ in wk 4$)$. Linear effect for week $(P<0.01)$ and cubic effect for time relative to feeding $(P<0.01)$. Color version available online.

radation is reduced when $\mathrm{pH}$ is below 5.5 (Bach et al., 2005). However, $\mathrm{pH}$ values in the Quigley et al. (1992) study were also below 5.5, so other factors are likely responsible for conflicting observations. Diet composition may be a contributing factor; the concentration of NDF in the starter tested by Quigley et al. (1992) was $37 \%$, whereas in the present study and in Uwituze et al. (2010), it was below 20\%. In addition, starch concentration was high in the present and Uwituze et al. (2010) studies, and starch can interfere with protein degradation (Bach et al., 2005).

\section{Particle Size, Starch Content, and pH of Feces}

Least squares means of particle size, starch content, and $\mathrm{pH}$ of feces are presented in Table 5 . The $\mathrm{X}_{\mathrm{gm}}$ of feces was greater for $\mathrm{W}$ than for $\mathrm{G}$ when analyzed with or without the soluble fraction, consistent with a greater particle size of diet and rumen contents at slaughter for $\mathrm{W}$ (Table 4). Retained $\mathrm{X}_{\mathrm{gm}}$ of feces in calves fed $\mathrm{W}$ was $47 \%$ larger than in calves fed $\mathrm{G}$; when the soluble fraction was added, $\mathrm{W}$ was only $18 \%$ greater. By comparison, $\mathrm{X}_{\mathrm{gm}}$ of $\mathrm{W}$ starter was $56 \%$ larger than $\mathrm{G}$ after adding the soluble fraction and 50\% larger when the soluble fraction was not included. These observations could be attributed to the contribution of milk replacer to the soluble fraction. However, there was a particle size reduction due to chewing; retained $\mathrm{X}_{\mathrm{gm}}$ of feces was 35 and $36 \%$ lower for $\mathrm{G}$ and $\mathrm{W}$, respectively, compared with that of starters. The proportion of particles retained on the 3.35-mm sieve of $\mathrm{W}$ was greater than the proportion retained for $\mathrm{G}$ and was compensated by $\mathrm{G}$ having greater proportions of retained material in the 5 lower sieves. The proportion of the soluble fraction was similar between diets. Total $\mathrm{X}_{\mathrm{gm}}$ of feces increased with age, which is consistent with a decrease in the soluble fraction; this is likely due to greater proportions of DMI coming from starter. The proportion of the soluble fraction in these calves was notably higher than those reported in heifers (Suarez-Mena et al., 2013b) and lactating cows (Maulfair et al., 2011). Retained $\mathrm{X}_{\text {gm }}$ did not change with age, which suggests that calves were able to reduce particle size of starter to a similar degree as starter intake increased.

No difference was detected in fecal pH (Figure 7), although it was numerically higher for the $\mathrm{W}$ treatment. Fecal $\mathrm{pH}$ decreased with age, which is consistent with rumen $\mathrm{pH}$ decreasing with age, and in response to increasing amounts of starter intake. Starch concentration of feces was higher for $\mathrm{W}$ than for G; this is likely in response to some oats in $\mathrm{W}$ passing through the digestive tract unbroken, which is confirmed by the greater proportion of fecal particles retained on the top screen (3.35 mm) for the W treatment. Allen (2011) observed that when diets contained either whole or steam-flaked corn, starch content of feces was similar preweaning but greater for the diet containing whole corn postweaning. Greater concentration of starch in feces suggests a lower digestibility of whole grains; indeed, when Porter et al. (2007) compared DM digestibility of mash and pellet starters, they observed that the mash starter had greater digestibility. Fecal starch concentration increased with age, which is comparable to the Allen (2011) study, in which feces from weaned calves had greater amounts of starch compared with preweaned calves. This is likely a result of greater starter intake increasing the rate of passage; however, low rumen $\mathrm{pH}$ could have affected starch digestion in the small intestine. Starch is digested in the rumen and absorbed as VFA. Starch that bypasses ruminal fermentation can be digested enzymatically in the small intestine and absorbed as less complex or free sugars, be digested in the large intestine and absorbed as VFA, or be excreted as part of the feces (NRC, 2001). Wheeler and Noller (1977) measured $\mathrm{pH}$ across the digestive tract of ruminants fed high-grain rations and determined that fecal $\mathrm{pH}$ is a reliable measure for intestinal $\mathrm{pH}$. In the present study, the distance from fecal $\mathrm{pH}$ to the optimal $\mathrm{pH}$ for pancreatic amylase activity (6.9; Russell et al., 1981) increased with calf age. It is possible that low rumen $\mathrm{pH}$ negatively influenced the acidity of digesta leaving the abomasum, which overwhelmed the small intestinal buffering capacity (Harrison and Hill, 1962; 


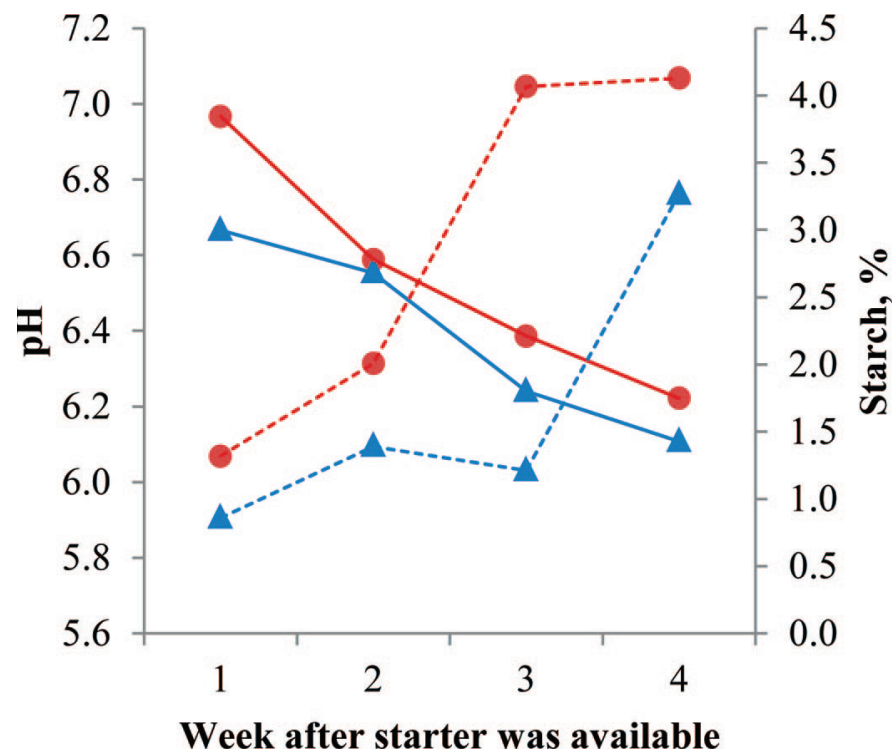

Figure 7. Mean fecal $\mathrm{pH}$ (solid lines) and starch (dashed lines) concentration from 1 to 4 wk after starter was available for calves fed ground $(\mathrm{n}=11$ calves up to wk 3 and 7 in wk $4 ; \mathbf{\Lambda})$ or whole oats $(\mathrm{n}=$ 13 calves up to wk 3 and $n=9$ in wk $4 ; \bullet$ ) in the starter. Diet effect for $\mathrm{pH}(P>0.10)$ and starch concentration $(P<0.01)$. Linear effect of week $(P<0.01)$ for both variables; diet by week interaction for starch $(P<0.05)$. Color version available online.

Wheeler and Noller, 1977), decreasing pancreatic amylase activity and the digestibility of starch. By wk 4, fecal pH was 6.2 , which in the small intestine would mean a $30 \%$ reduction in pancreatic amylase activity (Russell et al., 1981). In adult cattle, a grain-based SARA challenge increased the amount of starch bypassing rumen fermentation, increasing the concentration of free LPS (Li et al., 2012), which can negatively affect health of cattle (Plaizier et al., 2012). Thus, the increase in fecal starch concentration observed with increasing calf age in this study could have a negative effect on calf health.

\section{Digestive Organ Measurements}

Slaughter and rumen development measurements are presented in Table 6. Reticulorumen weight tended to be greater for $\mathrm{G}$ than for $\mathrm{W}$; however, this difference was not statistically significant when analyzed as a percentage of BW. Papillae length tended to be greater for $\mathrm{G}$ than for $\mathrm{W}$, consistent with a heavier reticulorumen. Similar results were observed by Greenwood et al. (1997), in which papillae length decreased as the particle size of starter diets increased, although no differences were detected in reticulorumen weight. Longer papillae for shorter particle size contrasts with findings by Beharka et al. (1998), where feeding a ground diet resulted in shorter papillae in the dorsal and dorsal blind sacs compared with feeding an unground diet. A possible explanation for this discrepancy is the length of time calves were kept on experimental diets, about 11 wk in Beharka et al. (1998), 6 wk in Greenwood et al. (1997), and 3 or 4 wk in the present study. Sampling location and measuring method are also inconsistent among studies, which could contribute to discrepancies. Longer papillae could be attributed to more-available nutrients for fermentation due to an increase in surface area with shorter grain particle size; this is supported in the present study by reduced fecal starch content in G. However, rumen fermentation observations in this study do not support this hypothesis, because $\mathrm{pH}$ was similar between diets. An alternative explanation is that the lack of abrasion in $\mathrm{G}$ permitted excessive keratinization of rumen epithelium, and papillae grew longer to compensate for the loss of absorptive surface area. McGavin and Morrill (1976) proposed that branching of rumen papillae occurs in compensation for a loss of absorptive capacity in response to thickening of the keratin layer. The secondary hypothesis of this study is based on the same principle and the Greenwood et al. (1997) observation that papillae length increases with increasing percent of keratin in epithelium. A thickening of the keratin layer in the rumen epithelium with decreased starter particle size was observed by Strusinska et al. (2009) in 90-d-old calves, even when calves on ground grain had access to hay and, in the last $2 \mathrm{wk}$, all calves had access to hay. In the present study, keratin layer and papillae shape were evaluated, but differences were not detected; however, numerical trends are in agreement with the findings of Greenwood et al. (1997). A score was assigned for keratin layer because its thickness was highly variable across each sample, making quantitative measures unreliable. The scale for scoring the keratin layer was developed from differences within the sample pool after a first evaluation and with the purpose of comparing treatments in this study. For this reason, the score of about 2.6 could mean that both experimental groups were affected by hyperkeratinization of the rumen epithelium or that neither group was affected. However, the high percentage of calves scored with abnormal papillae is indicative of some hyperkeratinization in both treatments. Moreover, numerical differences in the proportion of calves with abnormal papillae suggest that particle size of $\mathrm{W}$ did benefit the rumen. Lack of a difference might be related to the low number of observations; in other studies where papillae shape was discussed, no statistical analysis was reported or differences were not found (McGavin and Morrill, 1976; Greenwood et al., 1997; Beharka et al., 1998).

When trial 1 was analyzed by itself (Suarez-Mena et al., 2013a), omasum weight was greater for W; this difference vanished when trials 2 and 3 were added to the 
Table 6. Digestive system development measurements in calves fed starters containing ground oats in a pelleted feed $(\mathrm{G})$ or whole oats plus a pellet $(\mathrm{W})$

\begin{tabular}{|c|c|c|c|c|c|}
\hline \multirow[b]{2}{*}{ Item } & \multicolumn{4}{|c|}{ Diet } & \multirow[b]{2}{*}{$P$-value } \\
\hline & $\mathrm{G}$ & SEM & W & SEM & \\
\hline Calves, no. & 11 & - & 13 & - & \\
\hline \multicolumn{6}{|l|}{ Slaughter measurements } \\
\hline Carcass, kg & 45.3 & 1.0 & 44.4 & 0.9 & 0.52 \\
\hline Reticulorumen, g & 569 & 24 & 503 & 22 & 0.06 \\
\hline Omasum, g & 126 & 9 & 126 & 8 & 0.97 \\
\hline Abomasum, $\mathrm{g}$ & 240 & 9 & 274 & 8 & 0.01 \\
\hline Liver, $g$ & 1,194 & 45 & 1,236 & 41 & 0.50 \\
\hline Spleen, $\mathrm{g}$ & 165 & 297 & 178 & 240 & 0.97 \\
\hline \multicolumn{6}{|l|}{ Organ weight, $\%$ of BW } \\
\hline Reticulorumen & 0.93 & 0.04 & 0.85 & 0.04 & 0.15 \\
\hline Omasum & 0.21 & 0.01 & 0.21 & 0.01 & 0.76 \\
\hline Abomasum & 0.40 & 0.01 & 0.46 & 0.01 & $<0.01$ \\
\hline Liver & 1.99 & 0.06 & 2.09 & 0.05 & 0.21 \\
\hline Spleen & 0.28 & 0.01 & 0.30 & 0.01 & 0.09 \\
\hline \multicolumn{6}{|l|}{ Rumen } \\
\hline Papillae length, mm & 0.75 & 0.03 & 0.68 & 0.03 & 0.09 \\
\hline Papillae width, mm & 0.51 & 0.01 & 0.48 & 0.01 & 0.11 \\
\hline Rumen wall thickness, mm & 0.83 & 0.04 & 0.78 & 0.03 & 0.33 \\
\hline Abnormal papillae, ${ }^{1} \%$ & 54.55 & - & 38.46 & - & 0.68 \\
\hline Keratin layer, score ${ }^{2}$ & 2.72 & 0.40 & 2.50 & 0.36 & 0.69 \\
\hline \multicolumn{6}{|l|}{ Small intestine } \\
\hline Villus height, mm & 0.48 & 0.02 & 0.45 & 0.02 & 0.23 \\
\hline Crypt depth, mm & 0.27 & 0.01 & 0.24 & 0.01 & 0.08 \\
\hline
\end{tabular}

${ }^{1}$ Proportion of calves in which papillae were considered to have abnormal shape, blunted, and arborized.

${ }^{2}$ The keratin layer was scored, where $0=$ nonexistent and $5=$ maximum thickness.

analysis, and there was no interaction between trial and treatment. Other work has reported greater omasum size in diets with shorter particle size (Greenwood et al., 1997; Beharka et al., 1998). Beharka et al. (1998) attributed this observation to an increased flow of particles with shorter particle size from rumen to omasum, whereas Greenwood et al. (1997) credited it to greater muscular development. Changes in omasum weight have been reported when starter intake was affected by changing either starter starch source (Khan et al., 2008) or milk allowance (Suarez-Mena et al., 2011). In the present study, weight of abomasum was greater for $\mathrm{W}$ than for $\mathrm{G}$; increasing solid feed particle size by including forage in the diet increased abomasum weight in Castells et al. (2013) but had no effect in Webb et al. (2013). Changing particle size by processing had no effect on abomasum weight in the Greenwood et al. (1997) and Beharka et al. (1998) studies.

Crypt depth in the small intestine tended $(P=0.08)$ to be greater for $\mathrm{G}$, which is consistent with a trend $(P=0.08)$ for a trial $\times$ diet interaction in which villus height of $\mathrm{G}$ was greater than that of $\mathrm{W}$ (0.29 vs. $0.22 \mathrm{~mm}$ ) in trial 3. No differences between and within diet were detected in the different sections of the small intestine (data not shown). Our results contrast with those reported by Strusinska et al. (2009), in which feeding whole grain positively influenced small intestine morphometric structure. Differences in age at slaughter, proportion of whole grains in starter, forage provision, and intake differences between treatments in the above study may account for the conflicting results. The observations in the present study could be related to increased nutrient availability in the intestine for G, reflected by lower starch concentration in the feces in this treatment. Xylose absorption (Table 2) was not different between diets and no effect of week was detected, but a diet by week interaction was observed such that absorption was greater for $\mathrm{W}$ than for $\mathrm{G}$ in wk 2 .

\section{CONCLUSIONS}

Under the conditions of this study, physical form of oats in calf starter did not affect rumen $\mathrm{pH}$ and had little effect on rumen VFA and $\mathrm{NH}_{3}$ concentrations over time. Particle size of starter was decreased by grinding oats, and the same trend was observed in rumen contents and fecal particle size, which was greater for W. Starch content of feces was greater for W, suggesting that grinding oats improved starch digestibility. Reticulorumen weight and rumen papillae tended to be larger and small intestinal crypts were deeper for G, possibly because of the greater nutrient availability for that treatment. These results did not support the hypothesis that feeding whole oats compared with ground oats 
would increase rumen development. Lack of effects on $\mathrm{pH}$ and minimal changes in rumen fermentation could be related to calves being on the experimental diets for 3 and $4 \mathrm{wk}$ only, and the unground fraction of $\mathrm{W}$ diet being only $25 \%$ (a level at which it did not add enough texture to detect a difference). In addition, the high starch content of the ration may have overshadowed particle size effects.

\section{ACKNOWLEDGMENTS}

We thank J. S. Fisher from the Animal Diagnostic Laboratory in The Pennsylvania State University (University Park, PA) for evaluating rumen papillae shape and keratin layer.

\section{REFERENCES}

Allen, J. D. 2011. Use of a near-infrared spectrophotometer to predict nutrient composition of feces from feedlot Holstein cattle and its applicability for on-site research and industry use. PhD Diss. University of Arizona, Tucson.

Anderson, K. L., T. G. Nagaraja, J. L. Morrill, T. B. Avery, S. J. Galitzer, and J. E. Boyer. 1987. Ruminal microbial development in conventionally or early-weaned calves. J. Anim. Sci. 64:12151226.

AOAC International. 2000. Official Methods of Analysis. 17th ed. AOAC International, Arlington, VA.

ASABE (American Society of Agricultural and Biological Engineers). 2007. Method of determining and expressing particle size of chopped forage materials by screening. ANSI/ASAE. S424. 1:663665. Am. Soc. Agric. Biol. Eng., St. Joseph, MI.

Bach, A., S. Calsamiglia, and M. D. Stern. 2005. Nitrogen metabolism in the rumen. J. Dairy Sci. 88(E-Suppl.):E9-E21.

Beharka, A. A., T. G. Nagaraja, J. L. Morrill, G. A. Kennedy, and R. D. Klemm. 1998. Effects of form of the diet on anatomical, microbial, and fermentative development of the rumen of neonatal calves. J. Dairy Sci. 81:1946-1955.

Briggs, P. K., J. P. Hogan, and R. L. Reid. 1957. The effect of volatile fatty acids, lactic acid and ammonia on rumen $\mathrm{pH}$ in sheep. Aust. J. Agric. Res. 8:674-690.

Castells, L., A. Bach, A. Aris, and M. Terré. 2013. Effects of forage provision to young calves on rumen fermentation and development of the gastrointestinal tract. J. Dairy Sci. 96:5226-5236.

Chaney, A. L., and E. P. Marbach. 1962. Modified reagents for determination of urea and ammonia. Clin. Chem. 8:130-132.

Coverdale, J. A., H. D. Tyler, J. D. Quigley, and J. A. Brumm. 2004. Effect of various levels of forage and form of diet on rumen development and growth in calves. J. Dairy Sci. 87:2554-2562.

Covington, A. K., R. G. Bates, and R. A. Durst. 1985. Definition of $\mathrm{pH}$ scales, standard reference values, measurement of $\mathrm{pH}$ and related terminology (Recommendations 1984). Pure Appl. Chem. $57: 531-542$.

Dijkstra, J., H. Boer, J. Van Bruchem, M. Bruining, and S. Tamminga. 1993. Absorption of volatile fatty acids from the rumen of lactating dairy cows as influenced by volatile fatty acid concentration, $\mathrm{pH}$ and rumen liquid volume. Br. J. Nutr. 69:385-396.

Doehlert, D. C., M. S. McMullen, and J. L. Jannink. 2006. Oat grain/ groat size ratios: A physical basis for test weight. Cereal Chem. J. $83: 114-118$.

Greenwood, R. H., J. L. Morrill, E. C. Titgemeyer, and G. A. Kennedy. 1997. A new method of measuring diet abrasion and its effect on the development of the forestomach. J. Dairy Sci. 80:2534-2541.
Hall, M. B. 2009. Analysis of starch, including maltooligosaccharides, in animal feeds: A comparison of methods and recommended method for AOAC collaborative study. J. AOAC Int. 92:42-49.

Harrison, F. A., and K. J. Hill. 1962. Digestive secretions and the flow of digesta along the duodenum of the sheep. J. Physiol. $162: 225-243$.

Hodgson, J. 1971. The development of solid food intake in calves. 1. The effect of previous experience of solid food, and the physical form of the diet, on the development of food intake after weaning. Anim. Prod. 13:15-24.

Huber, J. T. 1969. Development of the digestive and metabolic apparatus of the calf. J. Dairy Sci. 52:1303-1315.

Karkalas, J. 1985. An improved enzymic method for the determination of native and modified starch. J. Sci. Food Agric. 36:1019-1027.

Khan, M. A., H. J. Lee, W. S. Lee, H. S. Kim, S. B. Kim, S. B. Park, K. S. Baek, J. K. Ha, and Y. J. Choi. 2008. Starch source evaluation in calf starter: II. Ruminal parameters, rumen development, nutrient digestibilities, and nitrogen utilization in Holstein calves. J. Dairy Sci. 91:1140-1149.

Kleen, J. L., G. A. Hooijer, J. Rehage, and J. P. T. M. Noordhuizen 2003. Subacute ruminal acidosis (SARA): A review. J. Vet. Med. A Physiol. Pathol. Clin. Med. 50:406-414.

Krause, K. M., and G. R. Oetzel. 2006. Understanding and preventing subacute ruminal acidosis in dairy herds: A review. Anim. Feed Sci. Technol. 126:215-236.

Laarman, A. H., T. Sugino, and M. Oba. 2012. Effects of starch content of calf starter on growth and rumen $\mathrm{pH}$ in Holstein calves during the weaning transition. J. Dairy Sci. 95:4478-4487.

Lesmeister, K. E., and A. J. Heinrichs. 2004. Effects of corn processing on growth characteristics, rumen development, and rumen parameters in neonatal dairy calves. J. Dairy Sci. 87:3439-3450.

Lesmeister, K. E., P. R. Tozer, and A. J. Heinrichs. 2004. Development and analysis of a rumen tissue sampling procedure. J. Dairy Sci. $87: 1336-1344$

Li, S., E. Khafipour, D. O. Krause, A. Kroeker, J. C. RodriguezLecompte, G. N. Gozho, and J. C. Plaizier. 2012. Effects of subacute ruminal acidosis challenges on fermentation and endotoxins in the rumen and hindgut of dairy cows. J. Dairy Sci. 95:294-303.

Maulfair, D. D., M. Fustini, and A. J. Heinrichs. 2011. Effect of varying total mixed ration particle size on rumen digesta and fecal particle size and digestibility in lactating dairy cows. J. Dairy Sci. 94:3527-3536.

Maulfair, D. D., and A. J. Heinrichs. 2010. Technical note: Evaluation of procedures for analyzing ration sorting and rumen digesta particle size in dairy cows. J. Dairy Sci. 93:3784-3788.

McGavin, M. D., and J. L. Morrill. 1976. Scanning electron microscopy of ruminal papillae in calves fed various amounts and forms of roughage. Am. J. Vet. Res. 37:497-508.

Merritt, A. M., and P. Duelly. 1983. Phloroglucionol microassay for plasma xylose in dogs and horses. Am. J. Vet. Res. 44:2184-2185.

NRC. 2001. Nutrient Requirements of Dairy Cattle. 7th rev. ed. Natl. Acad. Press, Washington, DC.

Plaizier, J. C., E. Khafipour, S. Li, G. N. Gozho, and D. O. Krause. 2012. Subacute ruminal acidosis (SARA), endotoxins and health consequences. Anim. Feed Sci. Technol. 172:9-21.

Porter, J. C., R. G. Warner, and A. F. Kertz. 2007. Effect of fiber level and physical form of starter on growth and development of dairy calves fed no forage. Prof. Anim. Sci. 23:395-400.

Quigley, J. D., T. M. Steen, and S. I. Boehms. 1992. Postprandial changes of selected blood and ruminal metabolites in ruminating calves fed diets with or without hay. J. Dairy Sci. 75:228-235.

Reid, R. L., J. P. Hogan, and P. K. Briggs. 1957. The effect of diet on individual volatile fatty acids in the rumen of sheep, with particular reference to the effect of low rumen $\mathrm{pH}$ and adaptation on high-starch diets. Aust. J. Agric. Res. 8:691-710.

Robertson, J. B., and P. J. Van Soest. 1981. The detergent system of analysis and its application to human foods. Pages 123-158 in The Analysis of Dietary Fiber in Foods. W. P. T. James and O. Theander, ed. Marcel Dekker Inc., New York, NY. 
Russell, J. R., A. W. Young, and N. A. Jorgensen. 1981. Effect of dietary corn starch intake on pancreatic amylase and intestinal maltase and $\mathrm{pH}$ in cattle. J. Anim. Sci. 52:1177-1182.

Slyter, L. L. 1986. Ability of $\mathrm{pH}$-selected mixed ruminal microbial populations to digest fiber at various pHs. Appl. Environ. Microbiol. 52:390-391.

Steele, M. A., O. AlZahal, S. Hook, J. Croom, and B. McBride. 2009. Ruminal acidosis and the rapid onset of ruminal parakeratosis in a mature dairy cow: A case report. Acta Vet. Scand. 51:39-44.

Steele, M. A., J. Croom, M. Kahler, O. AlZahal, S. E. Hook, K. Plaizier, and B. W. McBride. 2011a. Bovine rumen epithelium undergoes rapid structural adaptations during grain-induced subacute ruminal acidosis. Am. J. Physiol. Regul. Integr. Comp. Physiol. 300:R1515-R1523.

Steele, M. A., G. Vandervoort, O. AlZahal, S. E. Hook, J. C. Matthews, and B. W. McBride. 2011b. Rumen epithelial adaptation to high-grain diets involves the coordinated regulation of genes involved in cholesterol homeostasis. Physiol. Genomics 43:308-316.

Strusinska, D., D. Minakowski, G. Bomba, I. Otrocka-Domagala, M. Wisniewska, and J. Tywonczuk. 2009. Effect of whole cereal grains contained in the ration on calf performance and selected morphometric parameters of the rumen and small intestine. Czech J. Anim. Sci. 54:540-551.

Suarez-Mena, F. X., A. J. Heinrichs, T. M. Hill, and C. M. Jones. 2013a. Whole oats effects on digestive system development in neonatal dairy calves. J. Dairy Sci. 96(E-Suppl. 1):96. (Abstr.)

Suarez-Mena, F. X., T. M. Hill, A. J. Heinrichs, H. G. Bateman, J. M. Aldrich, and R. L. Schlotterbeck. 2011. Effects of including corn distillers dried grains with solubles in dairy calf feeds. J. Dairy Sci. 94:3037-3044.

Suarez-Mena, F. X., G. J. Lascano, and A. J. Heinrichs. 2013b. Chewing activities and particle size of rumen digesta and feces of precision-fed dairy heifers fed different forage levels with increasing levels of distillers grains. J. Dairy Sci. 96:5184-5193.
Terré, M., E. Pedrals, A. Dalmau, and A. Bach. 2013. What do preweaned and weaned calves need in the diet: A high fiber content or a forage source? J. Dairy Sci. 96:5217-5225.

Uwituze, S., G. L. Parsons, M. K. Shelor, B. E. Depenbusch, K. K. Karges, M. L. Gibson, C. D. Reinhardt, J. J. Higgins, and J. S. Drouillard. 2010. Evaluation of dried distillers grains and roughage source in steam-flaked corn finishing diets. J. Anim. Sci. $88: 258-274$.

Van Soest, P. J., J. B. Robertson, and B. A. Lewis. 1991. Methods for dietary fiber, neutral detergent fiber, and nonstarch polysaccharides in relation to animal nutrition. J. Dairy Sci. 74:3583-3597.

Warner, R. G., J. C. Porter, and S. T. Slack. 1973. Calf starter formulation for neonatal calves fed no hay. Pages 116-122 in Proc. Cornell Nutr. Conf., Cornell Univ., Ithaca, NY.

Webb, L. E., E. A. M. Bokkers, L. F. M. Heutinck, B. Engel, W. G. Buist, T. B. Rodenburg, N. Stockhofe-Zurwieden, and C. G. Van Reenen. 2013. Effects of roughage source, amount, and particle size on behavior and gastrointestinal health of veal calves. J. Dairy Sci. 96:7765-7776.

Weigand, E., J. W. Young, and A. D. McGilliard. 1972. Extent of butyrate metabolism by bovine ruminoreticulum epithelium and the relationship to absorption rate. J. Dairy Sci. 55:589-597.

Wheeler, W. E., and C. H. Noller. 1977. Gastrointestinal tract pH and starch in feces of ruminants. J. Anim. Sci. 44:131-135.

Williams, P. E. V., and A. J. Frost. 1992. Feeding the young ruminant. Pages 109-118 in Neonatal Survival and Growth. Occasional Publ. No. 15. M. Varley. P. E. V. Williams, and T. L. J. Lawrence, ed. Br. Soc. Anim. Prod., Edinburgh, UK.

Yang, C.-M. J., and G. A. Varga. 1989. Effect of three concentrate feeding frequencies on rumen protozoa, rumen digesta kinetics, and milk yield in dairy cows. J. Dairy Sci. 72:950-957. 